\title{
Identifikasi Sumber Pendapatan Asli Daerah pada Pajak Daerah Kota Jambi
}

\author{
Iqra Wiarta $^{1^{*}}$; Rahmi Handayani ${ }^{2}$; Arman Syafa ${ }^{2}{ }^{3}$; Aulia Yunica Harly ${ }^{4}$ \\ 1,2,3,4Fakultas Ekonomi dan Bisnis Universitas Muhammadiyah Jambi \\ Correspondence email: iqra_wiarta2006@yahoo.co.id handayani.rahmi@gmail.com armansyafaat177@gmail.com, \\ auliayunichaharly@gmail.com
}

\begin{abstract}
The focus of this research is to identify the original source of income in jambi city area, one of which is local taxes. Local taxes are an option in this study due to its enormous contribution to the original income of the region in the city of Jambi. This research aims to find out how much local tax growth, the effectiveness of local taxes, its contribution to the original income of the jambi city area and the classification of local taxes based on overlay theory. The method used is quantitative descriptive with data using secondary data. The results of the study showed the average growth of jambi city tax from 2018 to 2019 at $19.54 \%$, with a contribution of $65.05 \%$. The level of total local tax effectiveness is very effective in 2018 and 2019. The identification results showed that of the 9 (nine) regional tax sources 6 (six) were categorized as prime, 2 (two) potential and 1 (one) backward.
\end{abstract}

Keywords: Regional Finance, Local Taxes, and Local Native Income

\section{Pendahuluan}

Keuangan daerah didefinisikan sebagai semua hak dan kewajiban dalam rangka menyelengarakan pemerintahan daerah yang dapat dinilai dengan uang termasuk didalamnya segala segala bentuk kekayaan yang berhubungan dengan hak dan kewajiban daerah tersebut. Sehingga keuangan daerah berkaitan langsung dengan tujuan pencapaian pembangunan. Semakin baik kinerja keuangan daerah maka akan berdampak terhadap kesejahteraan masyarakat. Ada empat indikator yang mencerminkan kinerja keuangan daerah yaitu ketergantungan fiskal, kapasitas pencipataan pendapatan, proporsi belanja modal dan kontribusi sektor pemerintah (Herlin, 2021). Penelitian yang dilakukan Ridwan dkk (2017) menunjukan peningkatan terhadap Pendapatan Asli Daerah (PAD) Kabupaten/Kota se Provinsi Jambi, dengan adanya peningkatan tersebut akan mengambarkan kemampuan daerah dalam mengali sumbersumber penerimaan cukup berhasil dengan kata lain bahwa indikator ketergantungan fiskal dapat dilihat pada Pertumbuhan pendapatan asli daerah (PAD). Menurut Santosa dan Rahayu (2005) Semakin besar PAD maka menunjukkan bahwa daerah itu mampu melaksanakan desentralisasi fiskal dan ketergantungan terhadap pemerintah pusat berkurang begitu pula sebaliknya. Beberapa komponen pendapatan asli daerah terdiri atas: Pajak daerah, Retribusi daerah, Hasil pengolahan kekayaan daerah dan pendapatan lain-lain yang sah.

Tabel 1

Kontribusi Sumber Pendapatan Asli Daerah Kota Jambi tahun 2019

\begin{tabular}{|l|r|}
\hline \multicolumn{1}{|c|}{ Sumber PAD } & Besaran Kontribusi \\
\hline Pajak Daerah & 65,05 \\
\hline Retrebusi Daerah & 9,80 \\
\hline Pendapatan lain-lain yang sah & 2,49 \\
\hline Hasil pengelolaan kekayaan daerah & 22,67 \\
\hline
\end{tabular}

Sumber : data diolah

Berdasarkan tabel diatas, diketahui bahwa kontribusi sumber pendapatan asli daerah kota Jambi pada tahun 2019 terbesar berasal dari Pajak daerah sebesar 65,05\%. Selanjutnya kontribusi dari pendapatan lain-lain yang sah sebesar 22,67\%, retribusi daerah sebesar 9,8\% dan kontribusi terendah sebesar 2,49\% berasal dari hasil pengolahan kekayaan daerah. Berdasarkan undang-undang No. 28 tahun 2009, pajak daerah merupakan salah satu sumber pendapatan daerah yang penting dalam membiayai penyelenggaran daerah dan pembangunan daerah untuk menetapkan otonomi yang luas, nyata dan bertanggung jawab. Penelitian ini bertujuan untuk mengetahui kontribusi terbesar pada pendapatan asli daerah kota Jambi berasal dari pajak daerah dan belum adanya penelitian yang melakukan identifikasi terhadap pajak daerah.

\section{Metode}

Metode penelitian yang digunakan untuk menjawab masalah dalam penelitian ini yaitu dengan melakukan analisis deskriptif kuantitatif. Metode analisis desekriptif merupakan suatu metode penelitian yang sering digunakan dalam ilmu sosial dengan tujuan untuk menggambarkan mengenai situasi ataupun kejadian, sedangkan analisis 
kuantitatifnya merupakan metode analisis yang melakukan perhitungan terhadap data-data yang bersifat pembuktian masalah (Daniel, 2018). Data penelitian bersumber pada data sekunder yang didapatkan dari Badan pusat statistik, dan juga data website pada kementrian keuangan republik Indonesia.

\section{Hasil}

Tabel 2

Efektivitas Pajak Daerah Kota Jambi tahun 2018 s/d 2019

\begin{tabular}{l|r|r|r}
\hline Tahun & Anggaran & Realisasi & \multicolumn{1}{c}{ \%Efektifitas } \\
\hline 2019 & Rp 223.000.000.000 & Rp 255.914.037.459 & 114,76 \\
2018 & Rp 199.980.000.000 & Rp 214.090.367.162 & 107,06 \\
\hline
\end{tabular}

Sumber : Data diolah

Menurut Noorain (2019) Efektivitas pajak daerah sendiri merupakan penilaian kinerja pemungutan pajak daerah yang dilakukan oleh Dinas Pendapatan daerah selama satu tahun anggaran, apakah sudah efektif ataupun belum yang dapat dilihat dari persentase penerimaan pajak daerah yang direalisasikan dibandingkan dengan target yang telah ditetapkan. Berdasarkan tabel 2 tersebut maka dapat disimpulkan bahwa pajak daerah kota Jambi pada tahun 2018 dan 2019 dinilai sudah sangat efektiv dengan persetasenya yaitu 114,76\% pada tahun 2019 dan 107,06\% pada tahun 2018.

Tabel 3

Besaran pertumbuhan Realisasi Pajak daerah kota Jambi tahun 2019

\begin{tabular}{lr}
\hline & Jenis Pajak \\
\hline Pajak Hotel & Pertumbuhan \\
Pajak Restoran & 46,84 \\
Pajak Hiburan & 71,6 \\
Pajak Reklame & $-17,73$ \\
Pajak Penerangan Jalan & 303,09 \\
Pajak Air Tanah & 5,06 \\
Pajak Parkir & $-16,94$ \\
Pajak BPHTP & 28,74 \\
Pajak Bumi dan Bangunan & $-2,92$ \\
\hline Sumbr:Data Diolah & 23,23 \\
\hline
\end{tabular}

Sumber : Data Diolah

Tabel 3 didapatkan bahwa besaran pertumbuhan pajak daerah kota Jambi pada tahun 2019 yaitu sebesar 49\% jika dibandingkan dengan tahun 2018. Peningkatan tersebut terbesar disumbangkan dari pajak reklame dengan besaran pertumbuhannya yaitu 303,09\%. Hasil evaluasi terhadap pertumbuhan pajak daerah dan efektifitas pajak daerah dijadikan sebagai dasar dari peneliti untuk melakukan identifikasi jenis pajak daerah kedalam klasifikasi prima, potensial, berkembang dan terkebelakang. Jumaili (2019) Adapun klasifikasi tersebut dapat digunakan sebagai bahan pertimbangan bagi pemerintah dalam menentukan kebijakan yang menyangkut peningkatan penerimaan asli daerah yang bersumber pada pajak daerah.

Ermayanti (2019) Pendapatan asli daerah menjadi indikator yang terpenting dalam menilai suatu kemandirian pemerintah daerah dibidang keuangan. berdasarkan tabel diatas, didapatkan data yaitu besaran kontribusi pajak kota Jambi terhadap Pendapatan Asli Daerah tertinggi yaitu pada pajak BPHTP dan Pajak restoran. Pajak BPHTP masuk dalam kategori potensial dikarenakan pertumbuhan dari pajak ini sendiri pada tahun 2019 menurun jika dibandingakan dengan 2018 dengan besaran kontribusinya yaitu sebesar 13,98\%. Adapun potensi pajak daerah dengan kategori terkebelakang yaitu pajak air tanah dengan kontribusinya hanya sebesar $0,04 \%$. Untuk itu diperlukan upaya lebih dari pemerintah kota Jambi dalam upaya meningkatkan potensi pajak daerah yang bersumber dari pajak air tanah. Diperlukan kesadaran dari masyarakat untuk melaporkan penggunaan sumber mata air dirumah mereka sehingga secara bersama-sama pemerintah dan masyarakat dapat berupaya meningkatkan pendapatan asli daerah kota Jambi.

Tabel 4

Klasifikasi dan Kontribusi pajak daerah terhadap pendapatan asli daerah Kota Jambi tahun 2019

\begin{tabular}{lrl}
\hline \multicolumn{1}{c}{ Jenis Pajak } & Kotribusi & Keterangan \\
\hline Pajak Hotel & 4,48 & Prima \\
Pajak Restoran & 13,96 Prima \\
Pajak Hiburan & 4,33 Pontensial \\
Pajak Reklame & 3,15 Prima \\
Pajak Penerangan Jalan & 17,2 Prima \\
Pajak Air Tanah & 0,04 Terkebelakang
\end{tabular}




\begin{tabular}{lrl} 
Pajak Parkir & 1,61 & Prima \\
Pajak BPHTP & 13,98 & Potensial \\
Pajak Bumi dan Bangunan & 6,3 & Prima \\
\hline
\end{tabular}

Sumber : Data diolah

\section{Simpulan}

Berdasarkan pada hasil penelitian, peneliti dapat mengambil kesimpulan sebagai jawaban terhadap permasalahaan yang ada di perumusan penelitian. Adapun kesimpulannya yaitu sebagai berikut :

1. Secara umum pertumbuhan pajak daerah Kota Jambi pada tahun 2019 sebesar 19,54\% jika dibandingkan dengan tahun 2018 dengan besaran kontribusi terhadap Pendapatan Asli Daerah (PAD) kota Jambi yaitu sebesar 65,05\%.

2. Pajak daerah yang memiliki nilai overlay rendah yaitu pada pajak air tanah yaitu dengan keterangan terkebelakang, sedangkan pajak dengan penilaian potensial yaitu pajak hiburan dan pajak BPHTP. Adapun jenis pajak daerah lainnya berada pada posisi prima.

\section{Daftar Pustaka}

Daniel, P. A. (2018). Analisis pengaruh inflasi terhadap laju pertumbuhan ekonomi di Kota Jambi. Ekonomis: Journal of Economics and Business, 2(1), 131-136.

Ermayanti, H. D. (2019). Analisis Potensi Pajak Daerah Dalam Peningkatan Pendapatan Asli Daerah Kabupaten Magetan (Studi Kasus Pada BPPKAD Kab. Magetan), Doctoral dissertation, University of Muhammadiyah Malang).

Herlin, F., \& Hidayat, M. S. (2021). Studi komparatif kinerja keuangan daerah Kota Jambi dan Provinsi Jambi. Jurnal Paradigma Ekonomika, 16(3), 601-606.

Jumaili, S. (2019). Analisis Potensi Pajak Daerah di Kota Jambi. Jurnal Akuntansi \& Keuangan Unja, 4(1), 57-66.

Ridwan, A., Syaparuddin, S., \& Mustika, C. (2017). Pengaruh sumber pembiayaan desentralisasi fiskal terhadap Produk Domestik Regional Bruto dan tingkat kemiskinan (Studi di kabupaten-Kota di Provinsi Jambi). Jurnal Paradigma Ekonomika, 12(2), 87-99.

Santosa, P. B., \& Rahayu, R. P. (2005). Analisis Pendapatan Asli Daerah (PAD) dan Faktor-faktor yang mempengaruhinya dalam upaya pelaksanaan otonomi daerah di Kabupaten Kediri. Jurnal Dinamika Pembangunan (JDP), 2(1), 9-18.

Noorain, A., \& Syarifuddin Yahya, A. (2018). Analisis Efektivitas dan Kontribusi Pajak Daerah Sebagai Sumber Pendapatan Asli Daerah Kota Batu (Studi Pada Dinas Pendapatan Daerah Kota Batu Provinsi Jawa Timur). Jurnal JE \& KP, 2, 89-104. 